\title{
SYSTEM DYNAMICS MODELING OF KEY DETERMINANTS OF SOCIAL ECONOMIC DEVELOPMENT IN LATVIA
}

\author{
AleXei Homutinin ${ }^{1}$ \\ Daugavpils University (Latvia)
}

\begin{abstract}
The continuous reduction and aging of population poses a serious threat to social economic development in Latvia. The consequence may be an imbalance of the social budget and the pension system, lack of human resources, reduction of business activity, etc., which has the potential to cause deeper economic and political crisis. Particular importance in this context takes early identification of negative trends and development of adequate strategic decisions. Three hypothetical scenarios of social economic development in Latvia are generated using simulation model based on system dynamics methods. The novelty of research is the design of the model, range of selected factors and their structure, dependency between factors and time horizon. This made possible to calculate dynamics of population and its structure in dependence on GDP and average income.General trends for social economic development in Latvia are shown and several recommendations are offered. The research can be used for dynamic analysis in any specific field related to social economic development and demography.

KEY WORDS: social economic development, population age structure, simulation model, scenario analysis.
\end{abstract}

JEL CODES: E200, J110, O290, O410, C320, C530

\section{Introduction}

The most important single new certainty - if only because there is no precedent for it in all of history - is the collapsing birthrate in the developed world. In Western and Central Europe and in Japan, the birthrate has already fallen well below the rate needed to reproduce the population. But more important than absolute numbers is the age distribution within the population (Drucker, 2001, p. 44). The continuous reduction and aging of population, as well as high emigration and low fertility rate poses a serious threat to social and economic development also in Latvia. This can lead to growing demographic burden and imbalance of the social budget and the pension system, lack of human resources and reduction of business activity, degradation of education system at every level. All together this has the potential to cause deeper economic and political crisis. However, there is a whole range of actions to be taken for the stabilization of the social economic situation at the regional level. Among them could be different types of governmental support aimed to increase births, decrease emigration orto improve medical services, as well as development of strategies targeted to attract immigrants. But every decision has a consequence in long term period of time. Particular importance in this context takes early identification of negative trends and development of adequate strategic decisions, based on detailed analysis of possible after-effects.

Alexei Homutinin - Daugavpils University, Faculty of Social Sciences, Mg. oec., Dr. oec student. Scientific field - regional economics

E-mail: alexeihomutinin@gmail.com

Tel.: +37122022005 
The hypothesis is that the social economic development in Latvia is influenced by demographic changes, which are caused by the interplay of four demographic determinants: fertility rate (the average number of children that would be born to one woman during her lifetime); age specific death rate (the mean level of mortality in a given age group of population); migration (immigration and emigration); age structure of the population. The first three variables are predominantly independent from each other. Fertility rate is dependent on average income per person. The age structure is influenced by determinants and describes the distribution of the population in various age categories. Therefore, interaction of above-mentioned variables changes the population age structure over time.

Problem. The continuous reduction and aging of population poses a serious threat to social economic development in Latvia. This could be prevented by early identification of negative trends and development of adequate strategic decisions. Withal, existing world and regional scale simulation models were insufficient to predict the key social economic indicators at the national level.

Purpose. Social economic development indicators long-term forecast and analysis and estimation of results significancefor social economic policy improvement in Latvia.

Object. Dynamics of social economic development key indicators in Latvia.

Tasks:

- study previous experience of social economic model development and define the methodology and key parameters;

- createsimplified simulation model of social economic development in Latvia;

- calculatethree possiblescenarios of social economic development in Latvia, depending on GDP (Gross Domestic Product), average income and emigration;

- forecast long-term indicators of social economic development in Latvia;

- analyze and estimateforecast result significance for possible improvement of social economic policy in Latvia.

Methods. System dynamics; logical and statistical analysis; expert assessments; generalization.

\section{Social economic development modeling}

When we talk about real systems in the world surrounding us, we are really talking about models of these systems. We cannot grasp the full detail and complexity of the real world - and if we could, it would overtax our senses and information processing capacities. So we have to describe real systems by simplified and aggregated system representations, i.e. models that - hopefully - contain the essential features of the real system. All of our understanding of the world is in the form of models: from simple mental models to computer models. Models allow experimentation, and the outcomes guide our decisions. A given model is usually applicable only to a restricted range of conditions. It should never be applied outside its range of validity. To produce reliable information about dynamics, the processes producing dynamics in the model should be of the same kind as those we are trying to understand. That is difficult to achieve with mental models. Mathematical and computer models can be used to represent the essential structure of many real systems, and to reproduce the dynamic behavior implied by this system structure (Bossel, 2007b, p. 3).

There is a bulk of different models from national and up to world scale intended to forecast the social economic development. List of several well-known models is given in table 2. 
Table 1. World and regional scale models

\begin{tabular}{|c|c|c|c|c|}
\hline Authors & Model & Order parameters & Methods & Publications \\
\hline $\begin{array}{l}\text { J. Forrester } \\
\text { (The Club of Rome) }\end{array}$ & World 1,2 & $\begin{array}{l}\text { Population, Capital, } \\
\text { Capital share in } \\
\text { agriculture, } \\
\text { Nonrenewable } \\
\text { resources } \\
\text { Pollution }\end{array}$ & System dynamics & $\begin{array}{l}\text { J. W. Forrester (1971), } \\
\text { World Dynamics }\end{array}$ \\
\hline $\begin{array}{l}\text { D. Meadows, } \\
\text { J. Randers, } \\
\text { D. Meadows } \\
\text { (The Club of Rome) }\end{array}$ & World 3 & $\begin{array}{l}\text { Population, Capital } \\
\text { Capital share in } \\
\text { agriculture } \\
\text { Nonrenewable } \\
\text { resources } \\
\text { Pollution, } \\
\text { Governance }\end{array}$ & System dynamics & $\begin{array}{l}\text { D. Meadows, J. Randers, } \\
\text { D. Meadows (2012) } \\
\text { Limits to Grow }\end{array}$ \\
\hline $\begin{array}{l}\text { PWC (Price- } \\
\text { WaterhouseCoopers) }\end{array}$ & World in 2050 & $\begin{array}{l}\text { Demographics, } \\
\text { Education, Capital } \\
\text { investments, } \\
\text { Technological progress }\end{array}$ & $\begin{array}{l}\text { Mathematical macro } \\
\text { modeling based on } \\
\text { simplified model of } \\
\text { long-term economic } \\
\text { growth }\end{array}$ & $\begin{array}{l}\text { PWC (2013, p. 18) } \\
\text { World in } 2050 \\
\text { The BRICs and beyond: } \\
\text { prospects, challenges } \\
\text { and opportunities }\end{array}$ \\
\hline $\begin{array}{l}\text { J. Randers } \\
\text { (The Club of Rome) }\end{array}$ & $\begin{array}{l}\text { 2052. A Global } \\
\text { Forecast for the } \\
\text { Next Forty Years }\end{array}$ & $\begin{array}{l}\text { Population, Labor } \\
\text { force, Labor } \\
\text { productivity, GDP, } \\
\text { Consumption, Energy } \\
\text { use, CO2 emissions, } \\
\text { Climate change, Food } \\
\text { production, Ecological } \\
\text { footprint, Production, } \\
\text { Standart of living }\end{array}$ & $\begin{array}{l}\text { Mathematical } \\
\text { modeling, expert } \\
\text { assessments }\end{array}$ & $\begin{array}{l}\text { J. Randers }(2012, \text { p. } 58) \\
\text { 2052. A Global Forecast } \\
\text { for the Next Forty Years }\end{array}$ \\
\hline $\begin{array}{l}\text { P. Caratti, J. } \\
\text { Ravetz, M. Alvarez, } \\
\text { W. Schade } \\
\text { (European } \\
\text { Commission) }\end{array}$ & $\begin{array}{l}\text { INSURE } \\
\text { Flexible framework } \\
\text { for Indicators for } \\
\text { Sustainability in } \\
\text { Regions using } \\
\text { system } \\
\text { dynamics modeling }\end{array}$ & $\begin{array}{l}\text { Eurostat Sustainable } \\
\text { Development } \\
\text { indicators }\end{array}$ & System dynamics & $\begin{array}{l}\text { Final Report to } \\
\text { European Commission } \\
\text { (March 2007, EU } \\
\text { Framework programme } \\
\text { 6: Contract no. 505358) } \\
\text { M. Álvarez-Arenas, } \\
\text { I. Mirón (2006, p. 48) } \\
\text { A flexible framework } \\
\text { for regional sustainable } \\
\text { development } \\
\text { indicators using } \\
\text { system thinking } \\
\text { criteria (INSURE). } \\
\text { Revista Internacional } \\
\text { de Sostenibilidad, } \\
\text { Technologia y } \\
\text { Humanismo 2006, n. } 1\end{array}$ \\
\hline
\end{tabular}




\begin{tabular}{|l|l|l|l|l|}
\hline Authors & Model & Order parameters & Methods & Publications \\
\hline Millennium Institute & Threshold 21 & $\begin{array}{l}\text { Labor, Capital, } \\
\text { Technology, } \\
\text { Productivity, } \\
\text { Resources, Energy, } \\
\text { Prices etc. }\end{array}$ & $\begin{array}{l}\text { System dynamics } \\
\text { modeling based on } \\
\text { Cobb-Douglas } \\
\text { production functions }\end{array}$ & $\begin{array}{l}\text { E. Cimren, A. Bassi, } \\
\text { J. Fiksel (2010, p. 2818). } \\
\text { T21-Ohio, a System } \\
\text { Dynamics Approach to } \\
\text { Policy Assessmentfor } \\
\text { Sustainable } \\
\text { Development: A Waste } \\
\text { to Profit Case Study. } \\
\text { Sustainability 2010, } \\
\text { 2 (ISSN 2071-1050), } \\
\text { 2814-2832 }\end{array}$ \\
$\begin{array}{l}\text { V. A. Sadovnichiy, } \\
\text { A. A. Akayev; } \\
\text { Russian Academy of } \\
\text { Sciences }\end{array}$ & $\begin{array}{l}\text { World dynamics } \\
\text { and crisis modeling } \\
\text { and forecast }\end{array}$ & $\begin{array}{l}\text { Population, } \\
\text { Technologies, } \\
\text { Resources, Labor force }\end{array}$ & $\begin{array}{l}\text { Set of nonlinear } \\
\text { mathematical } \\
\text { models describing } \\
\text { demographic, } \\
\text { social economic } \\
\text { and political } \\
\text { development at } \\
\text { world, regional and } \\
\text { national levels }\end{array}$ & $\begin{array}{l}\text { V. A. Sadovnichiy, } \\
\text { A. A. Akayev, } \\
\text { Sorotayev, Y. Malkov (2012) }\end{array}$ \\
\hline
\end{tabular}

Main objects of social economic forecast are demographics, economics, social sphere, ecology and technical progress. They define the so-called order parameters - those slow variables, whose behavior influences all the other parameters. The key order parameters in world history have been and remain - population size $(N)$, available resources $(R)$ and the level of technology $(T)$. Typical indicators of socio-economic macro forecasting are:

- GDP (gross domestic product - Y) as a whole and per capita, output of major products, goods and services;

- population $(\mathrm{N})$ and labor $(\mathrm{L})$;

- investment (I) in fixed capital (K), in the industrial and social spheres;

- export (EX) and import (IM) of products and services;

- $\quad$ productivity $(\mathrm{T})$;

- Human Development Index (HDI) (V. A. Sadovnichiy, A. A. Akayev, A. V. Korotayev, S. Y. Malkov (2012, p. 14).

Historically, beginning with the first report to the Club of Rome made by Jay Forrester, model developers had often been using system dynamics methodology to study and describe the dynamics of complex systems.

2. System dynamics

System dynamics, according to Richardson "is a computer aided approach to policy analysis and design. It applies to dynamic problems - problems that involve change over time - arising in complex social, managerial, economic or ecological systems - literally any dynamic systems characterized by interdependence, mutual interaction, information feedback and circular causality" (Richardson, 1991, p. 144).

Besides, System dynamics is a method to enhance learning in complex systems (Sterman, 2000 , p. 4). Like all systems, the complex system is an interlocking structure of feedback loops... This loop structure surrounds all decisions public or private, conscious or unconscious. (Forrester, 1969, p. 107). 
The system dynamics approach involves:

- Defining problems dynamically, in terms of graphs over time.

- Striving for an endogenous, behavioral view of the significant dynamics of the system.

- Thinking of all concepts in the real system as continuous quantities interconnected in loops of information feedback and circular causality.

- Identifying independent stocks or accumulations in the system and their inflows and outflows.

- Formulating a behavioral model capable of reproducing, by itself, the dynamic problem of concern. The model is usually a computer simulation model expressed in nonlinear equations.

- Deriving understandings and policy insights from the resulting model.

- Implementing changes resulting from model-based understandings and insights (Richardson, 1991, p. 145).

Mathematically, the basic structure of a formal system dynamics computer simulation model is a system of coupled, nonlinear, first-order differential (or integral) equations (1):

$$
\frac{d}{d t} x(t)=f(x, p)
$$

where $x$ is a vector of levels (stocks or state variables), $p$ is a set of parameters, and $f$ is a nonlinear vectorvalued function (Richardson, 1991, p. 145).

Simulation of such systems is easily accomplished by partitioning simulated time into discrete intervals of length $d t$ and stepping the system through time one $d t$ at a time. Each state variable is computed from its previous value and its net rate of change $x(t)$ :

$$
x(t)=x(t-d t)+d t^{*} x(t-d t) \text { (Richardson, 1996, p. 807). }
$$

The behavior of a system arises from its structure. That structure consists of the feedback loops, stocks and flows, and nonlinearities created by the interaction of the physical and institutional structure of the system with the decision-making processes of the agents acting within it (Sterman, 2000, p. 107). Nonlinear systems generally cannot be solved and cannot be added together. Nonlinearity means that the act of playing the game has a way of changing the rules. That twisted changeability makes nonlinearity hard to calculate, but it also creates rich kinds of behavior that never occur in linear systems (Gleick, 1987, p. 23).

The feedback concept is at the heart of the system dynamics approach. Diagrams of loops of information feedback and circular causality are tools for conceptualizing the structure of a complex system. A feedback loop exists when information resulting from some action travels through a system and eventually returns in some form to its point of origin. The dynamic behavior arises from the temporal sequence of information that produces actions which have consequences generating further information and actions. Feedback is said to be negative when the modification in a component leads other components to respond by counteracting that change. Negative feedback is often the engine that drives supply and demand cycles toward some equilibrium. The word 'negative' does not imply a value judgment. Instead, it indicates that feedback tends to negate initial changes. Feedback is said to be positive when the original modification leads to changes that reinforce the component that started the process. In the same example as above, the migration of farm workers to a city attracts more manufacturers to open plants in that city, which attracts even more workers. Negative feedback processes tend to counteract a disturbance and lead systems back towards an equilibrium or steady state. One possible outcome of market mechanisms is that demand and supply balance each other or fluctuate around an equilibrium point, due to lagged adjustments in the productive or consumptive sector. In contrast, positive feedback processes tend to amplify any disturbance and to lead systems away from equilibrium (Ruth, Hannon, 1997, p. 8). 
Stocks and the flows that affect them are essential components of system structure. A map of causal influences and feedback loops is not enough to determine the dynamic behavior of a system. Stock variables are accumulations and indicate the status of the system through time. They are the basis for the calculation of all the rest of the variables in the model (Ruth, Hannon, 1997, p. 8).

The modeling process typically consists of 5 stages. According to J. Sterman these are:

- Problem articulation (boundary selection).

- Formulation of dynamic hypothesis.

- Formulation of a simulation model.

- Testing.

- Policy design and evaluation (Sterman, 2000, p. 86).

\section{Simulation model}

The modelis based on system dynamics method and is implemented using ISEE I think software. The model is conceived to generate hypothetical scenarios of social economic development using historical data since year 1996. As a result, following data can be obtained from the model for each scenario at any year up to 2050: population, population structure by age and sex, persons under and over working age, demographic burden and demographic burden structure, fertility rate, GDP per person, average income per person, natural population change. The input data is prepared and structured. Time horizon of all calculations is up to year 2050. This is long enough term for analysis on one hand, and realistic on the other, because most of residents determining population development in this period are already living today.

According to $\mathrm{H}$. Bossel, major errors arise primarily because a homogeneous population is assumed, where the number of births and deaths is proportional to total population. This simplification may be permissible for bacteria, but for human populations it obviously makes a difference whether the population consists mainly of children, adults of reproductive age, or old people. Old people contribute no longer, children not yet to reproduction. For computing correctly the number of births per year the number of women of childbearing age and their fertility must therefore be known (Bossel, 2007, p. 92).

For higher precision model aggregates separated but interconnected sub-models for female and male population development. This is done to calculate dynamics of population structure by age and sex. Each sub-model consists of 13 age groups: $0-14,15-19,20-24,25-29,30-34,35-39,40-44,45-49,50-54$, $55-59,60-64,65-69$, from 70 . First group refers to people under working age, the last group almost excludes active population, there fore these two groups represent non-active population. Age groups from 15 and up to 69 represent labor force. Initial data for each age group is being imported from input data file and refers to year 1996. Transition from one age group $x$ to the next (maturing) is done according to following equation (2):

$$
\text { maturing[age group } x+1 \text { ] = population[age group } x \text { ]/[age group } x \text { size (years)] }
$$

This means, for instance, that all persons from age group "35-39" will be transferred to the group " $40-44$ " within 5 years, but from group " $0-14$ " to the group " $15-19$ " within 15 years. The value of each age group $x$ at any time is calculated according to following equation (3):

$$
\begin{aligned}
\text { population[age group } x](t) & =\text { population[age group } x](t-d t)+(\text { maturing[age group } x-1]- \\
& - \text { maturing[age group } x+1]) * d t,
\end{aligned}
$$

where: $t$ - year of current calculations;

$d t$ - time interval (1 year in case of the simulation model). 
However, the model considers immigration, emigration and death factors as well, thus the complete equation is following (4):

$$
\begin{aligned}
\text { population[age group } x](t) & =\text { population[age group } x](t-d t)+(\text { maturing[age group } x-1]+ \\
\text { immigration[age group } x \text { ] - maturing[age group } x+1 \text { ] deaths[age group } x]- & \text { - emigration[age group } x]) * d t
\end{aligned}
$$

where: $t$ - year of current calculations,

$d t$ - time interval ( 1 year in case of the simulation model).

There is a reinforcing feedback to male and female age groups " $0-14$ ", which calculates the number of births each year. It's calculated by multiplication of fertile female population (age groups covered by range 15-45) and fertility rate for each period of time.Distribution between male and female newborns is done using mean value for recent 50 years and is $49 \%$ for male and $51 \%$ for female.

The model has been tested in two stages - using critical initial values and comparing results returned by simulation for period 1996-2012 to historical ones. The deviations between simulated historical demographic results and statistical data are in range $+/-1 \%$.

\section{Simulation results}

Three scenarios were calculated using assumptions as shown in table 2. First scenario assumes, that all rates will remain the same since year 2011 and during the whole time horizon. Second scenario refers to year 2007 emigration level, when the economy was in peak growth. Third scenario assumes "zero" emigration,

\begin{tabular}{|c|c|c|c|}
\hline \multirow{2}{*}{ Parameter /Scenario } & \multicolumn{3}{|c|}{ Parameter value for period of time $2014-2050$} \\
\hline & Scenario 1 & Scenario 2 & Scenario 3 \\
\hline Death rate & \multicolumn{3}{|c|}{ as to year 2011} \\
\hline Immigration rate & \multicolumn{3}{|c|}{ as to year 2011} \\
\hline Emigration rate & as to year 2011 & as to year $2007^{*}$ & $0.000 \%$ \\
\hline
\end{tabular}
becoming the most optimistic out of all.

Table 2. Parameter settings for model scenarios

Each scenario is done under assumption, that GDP will grow continuously according to OECD (Organization for Economic Co-operation and Development) forecast for EU27. Growth rates are following: 2.1 \% up to year 2020, then $2.0 \%$ up to year 2030 and $1.7 \%$ up to year 2050. GDP change in time is shown on figure 1 .

Average income is often used to measure a country's standard of living. It is usually expressed in terms of a commonly used international currency and has a strong correlation with GDP of 0.90 . Using least square method, linear function was calculated to determine the dependency of average income from GDP. Calculated data range for average income is graphically presented on figure 2 . 


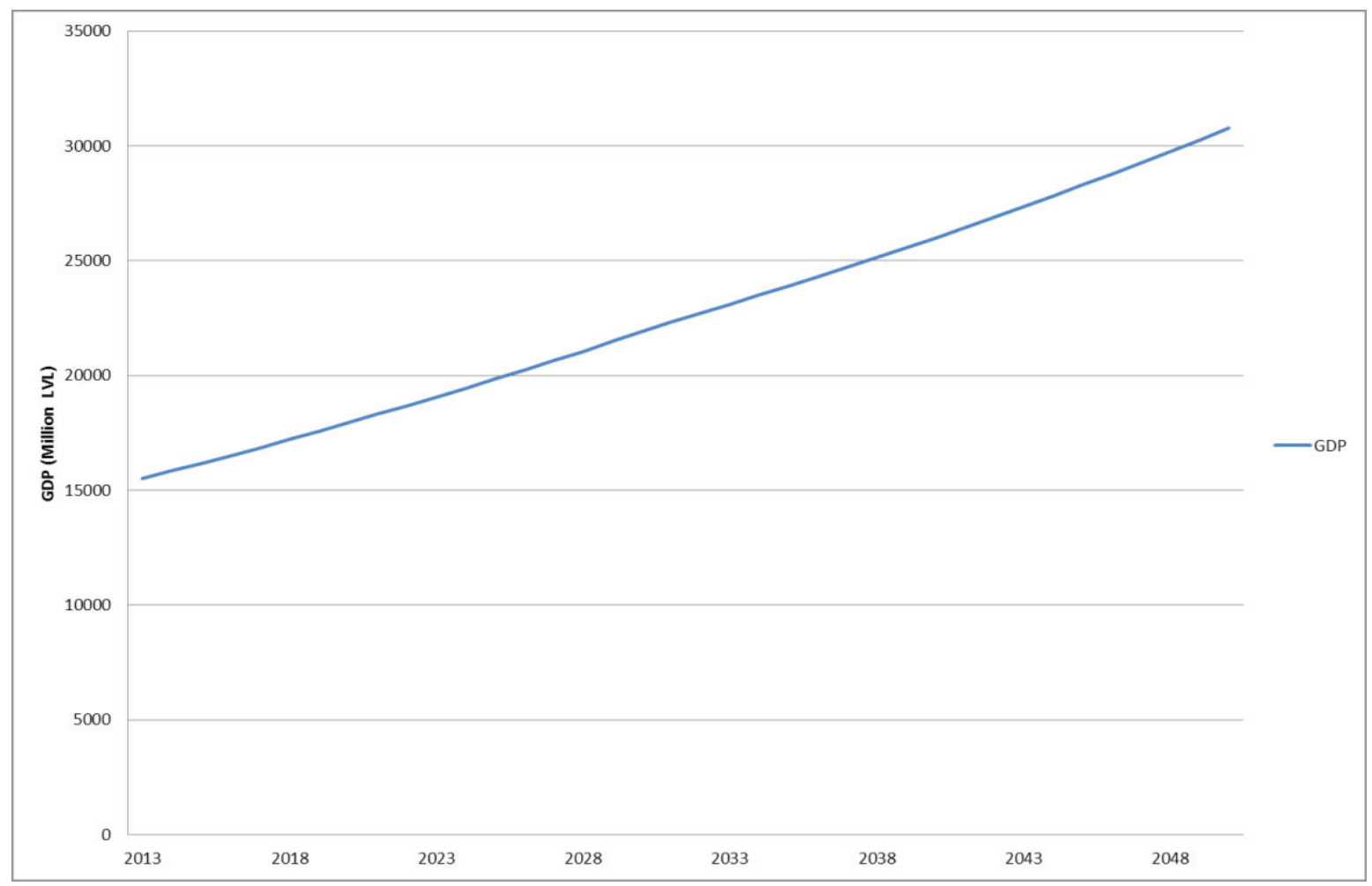

Figure 1. GDP growth up to 2050 (mil. LVL)

Source: author's calculations based on OECD data (Chateau, 2011, p. 22) and data from Central Statistical Bureau of Latvia [www.csb.gov.lv]

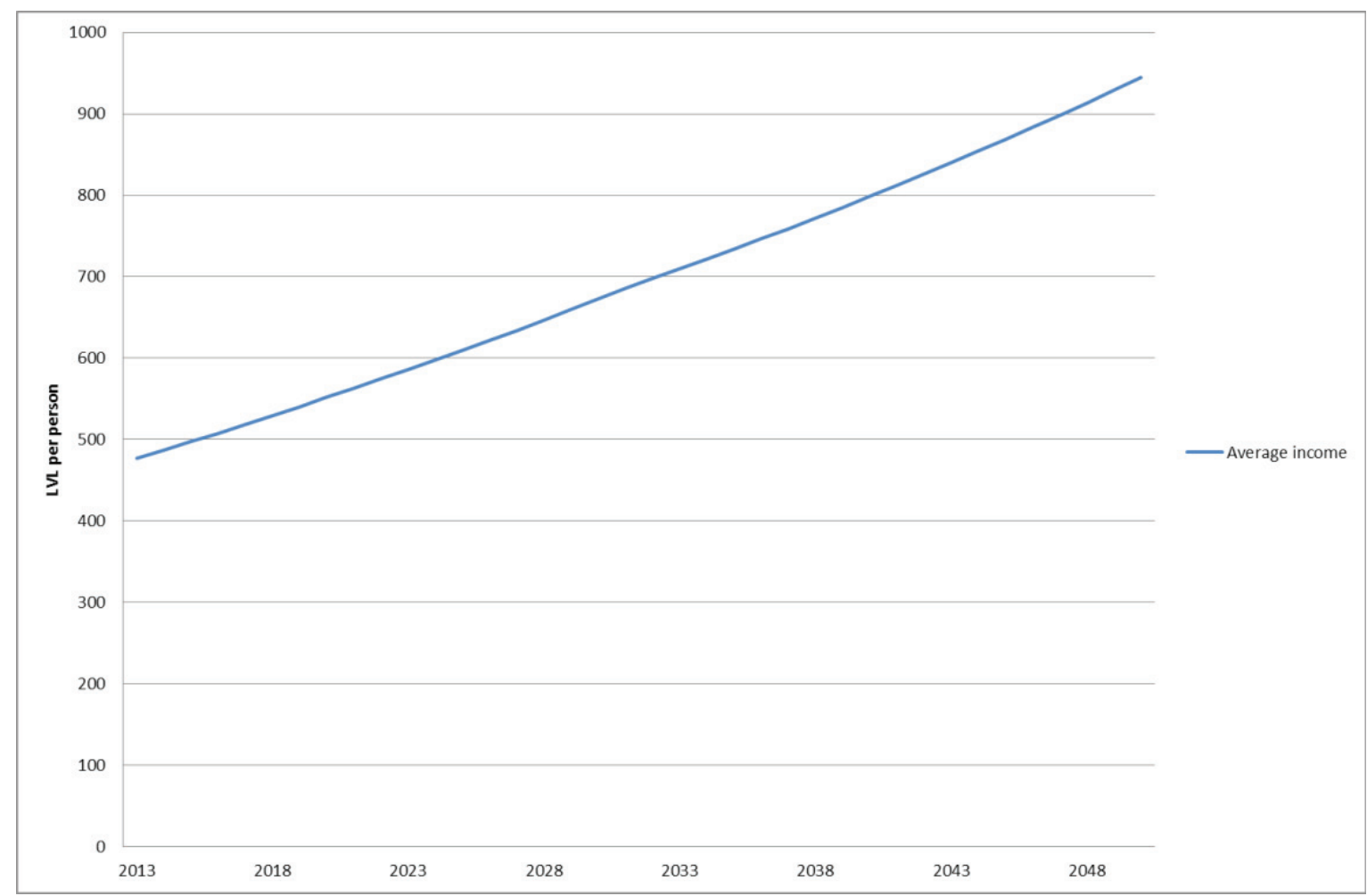

Figure 2. Average income per capita

Source: author's calculations based on data from Central Statistical Bureau of Latvia [www.csb.gov.lv]

Fertility rate, in turn, possibly depends on average income and has a very strong correlation of 0.98 with it. Linear function is determined using least squares method. Results are shown on figure 3. 


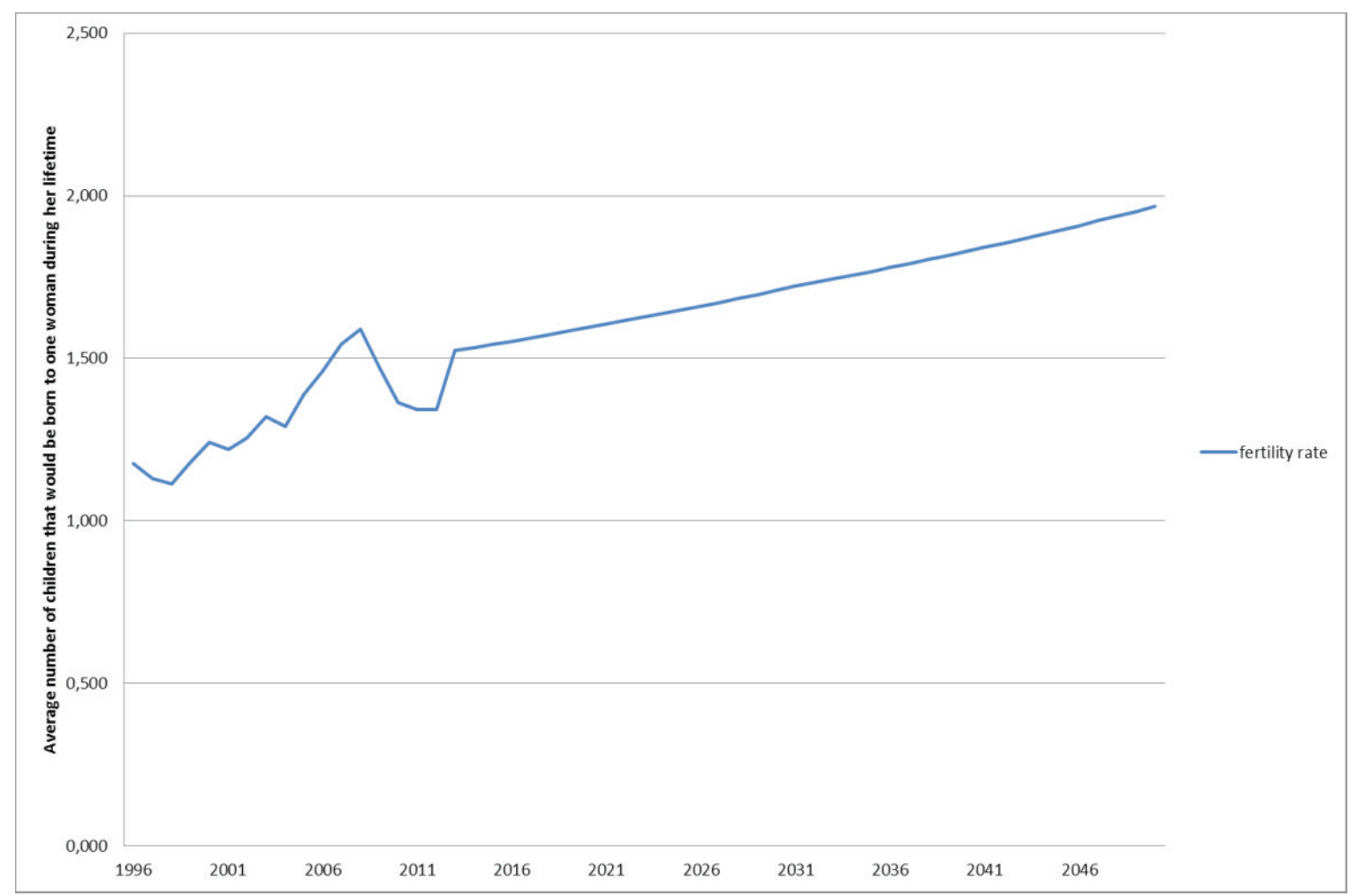

Figure 3. Fertility rate

Source: author's calculations based on data from Central Statistical Bureau of Latvia [www.csb.gov.lv]

Although, fertility rate is growing continuously up to value 1.96 by year 2050 , dynamics of births shows positive trends only for third scenario (Figure 4).

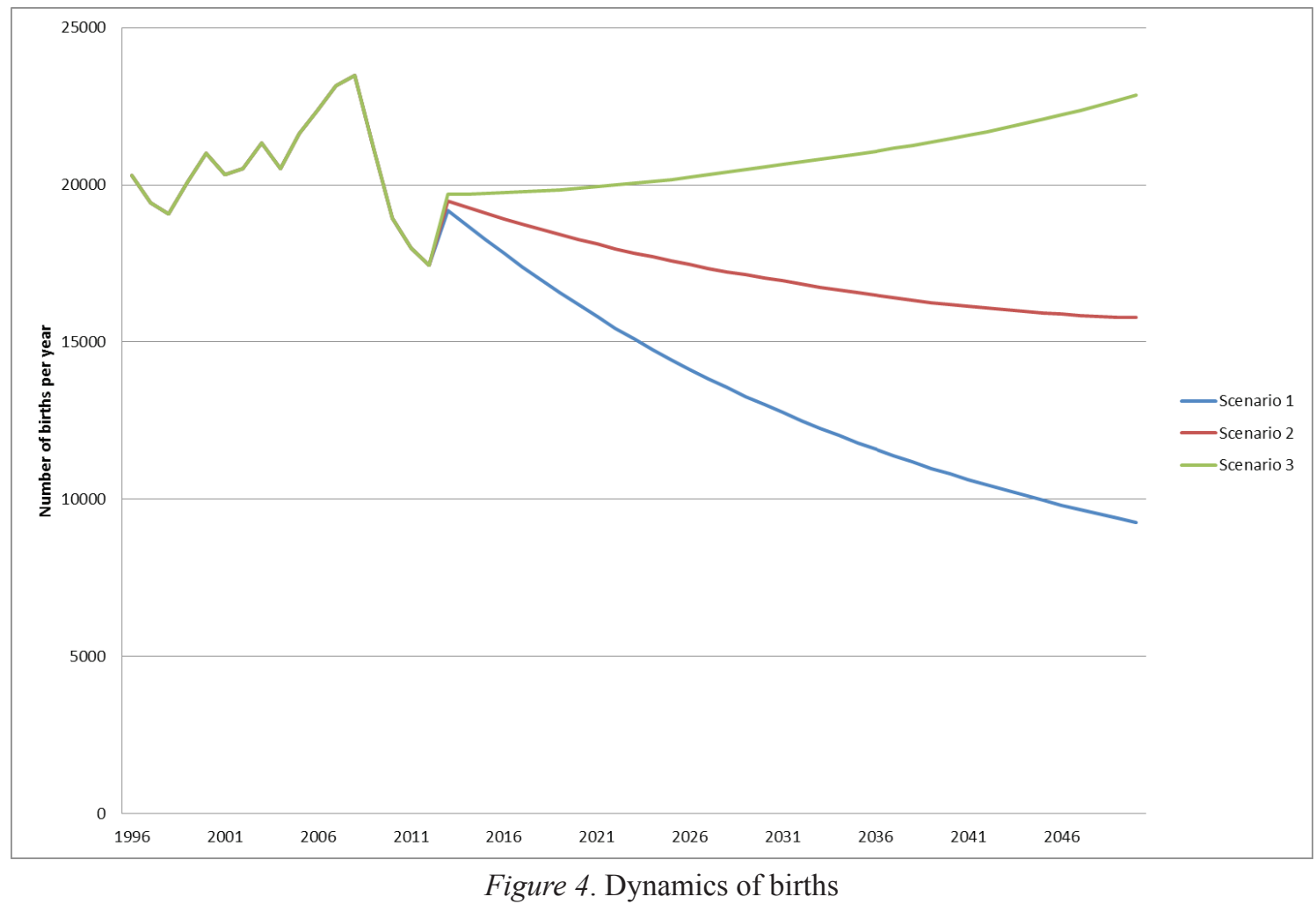

Source: author's calculations based on data from Central Statistical Bureau of Latvia [www.csb.gov.lv] 
This is mainly caused by continuously decreasing number of fertile age women. Dynamics of births is a key-driver of population dynamics (Figure 5).

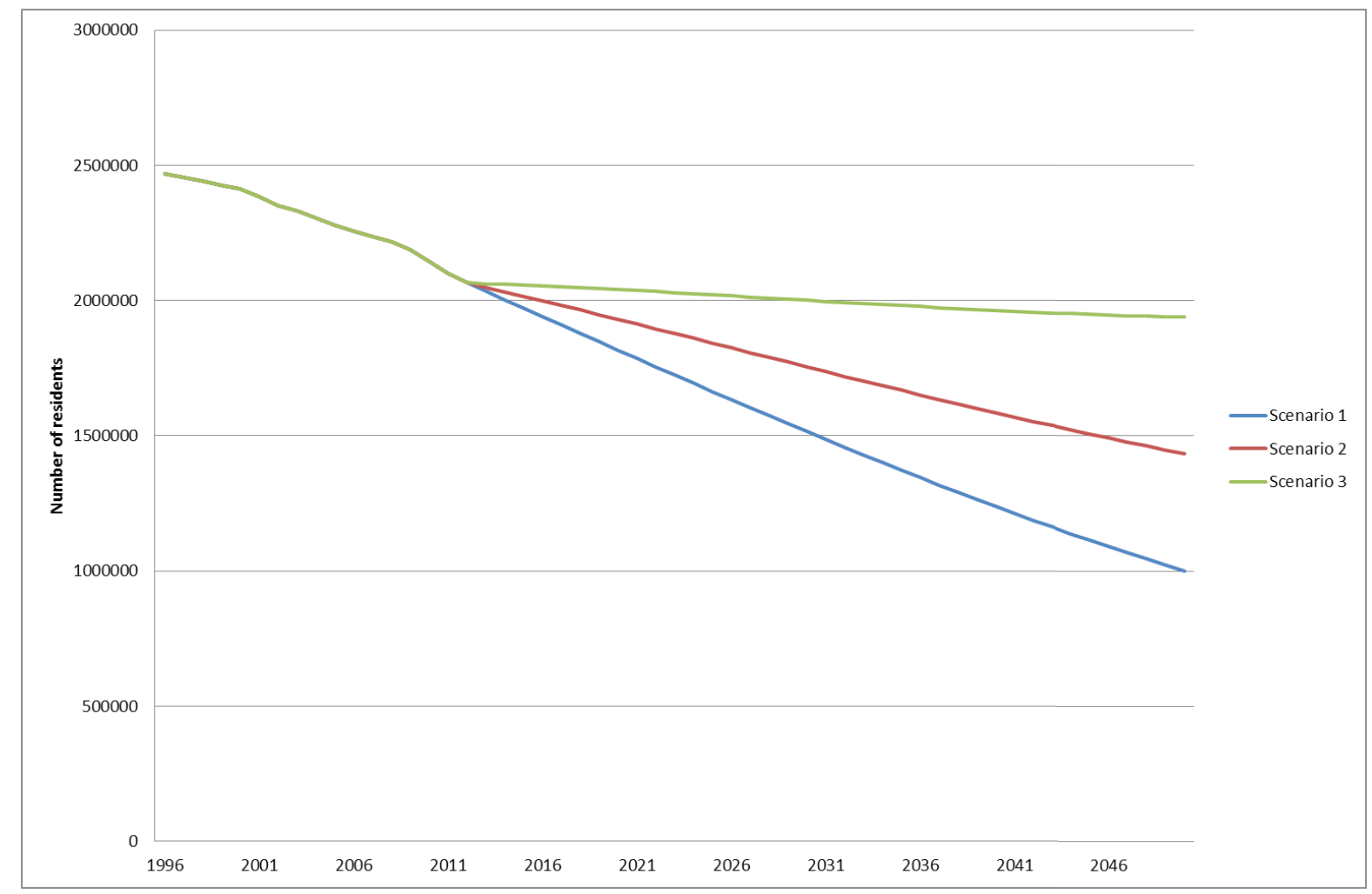

Figure 5. Population dynamics

Source: author's calculations based on data from Central Statistical Bureau of Latvia [www.csb.gov.lv]

As shown on the Figure 5, any scenario realization leads to decrease of population within selected time horizon. Even if "Zero" emigration is assumed (in case of third scenario), tendency for depopulation remains. Above-mentioned reasons will lead to demographic burden grow within time horizon from 560 and up to 860 persons under and over working age per 1000 of working age (Figure 6).

The main cause of growing demographic burden is population aging. Dynamics of employed labor force and people of retirement age, which generally forms the demographic burden, is shown on figure 7. 


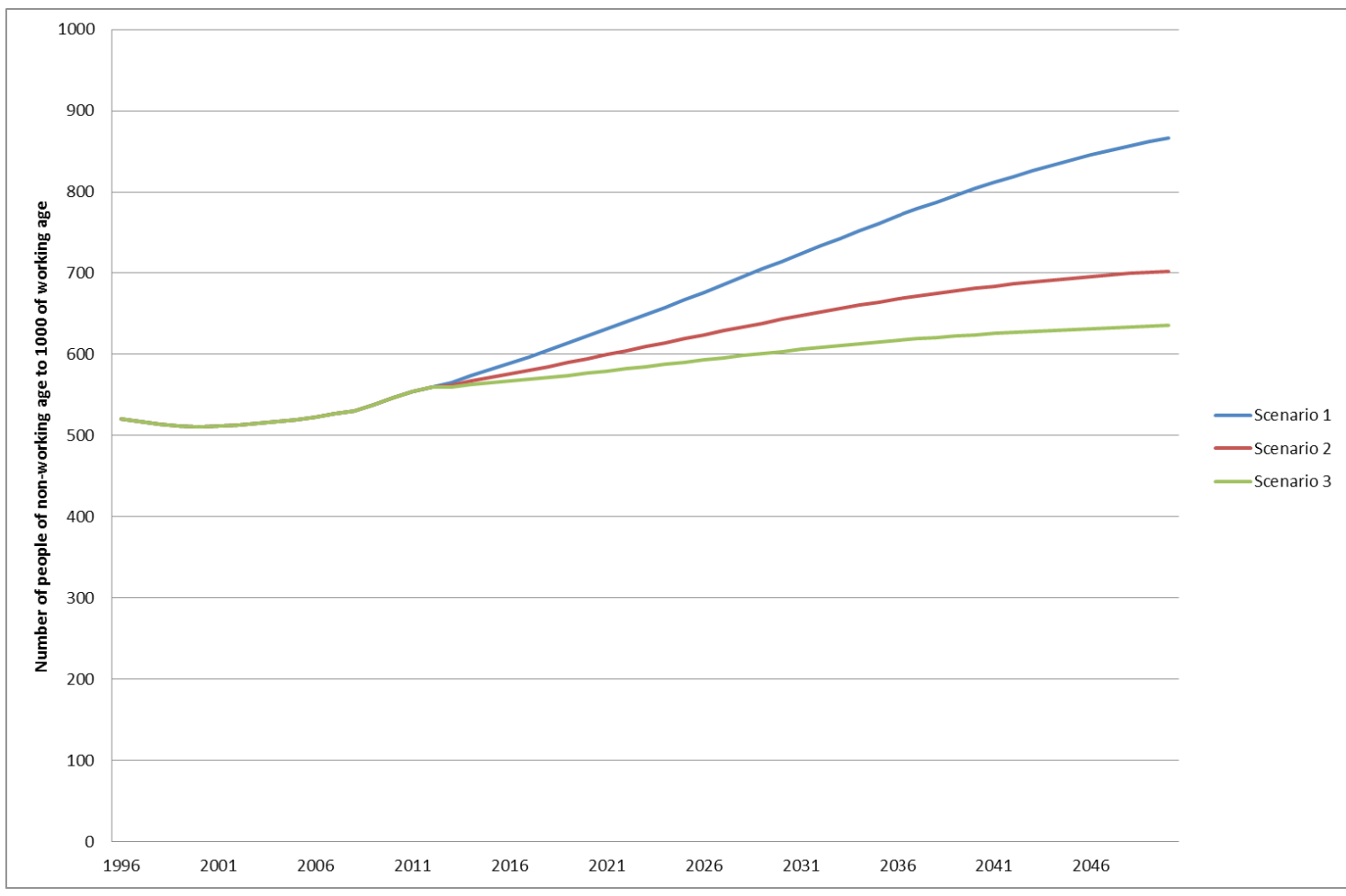

Figure 6. Demographic burden

Source: author's calculations based on data from Central Statistical Bureau of Latvia [www.csb.gov.lv]

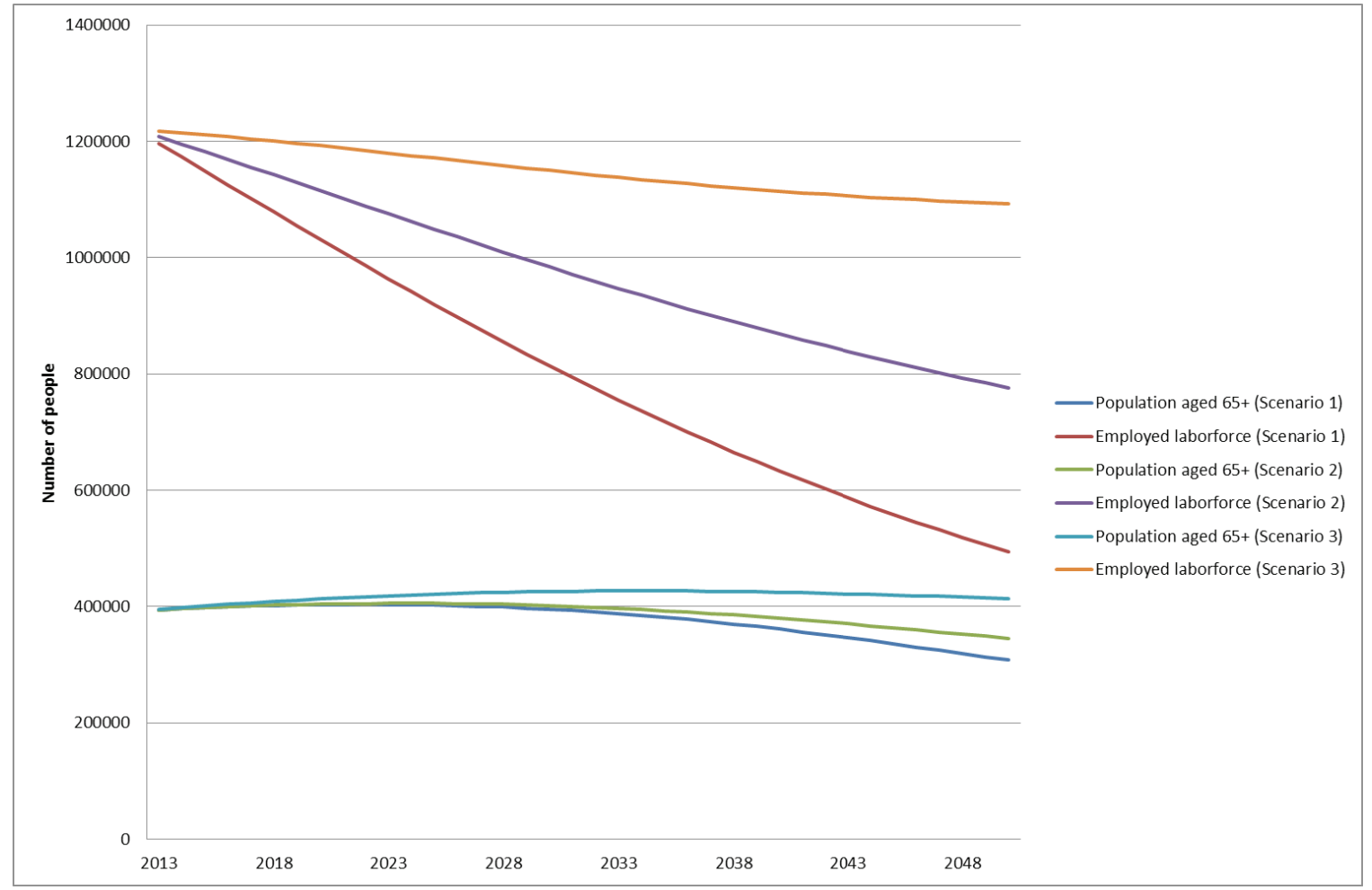

Figure 7. Population dynamics: employed labor force and people aged 65+

Source: author's calculations based on data from Central Statistical Bureau of Latvia [www.csb.gov.lv] 
Simulation results show continuous decline of labor force number for each scenario and light growth with subsequent decrease of number of people aged 65 and over. Thiscan be explained by age structure analysis in dynamics. Age structure change for the first scenario is presented on figures 8, 9, 10 .

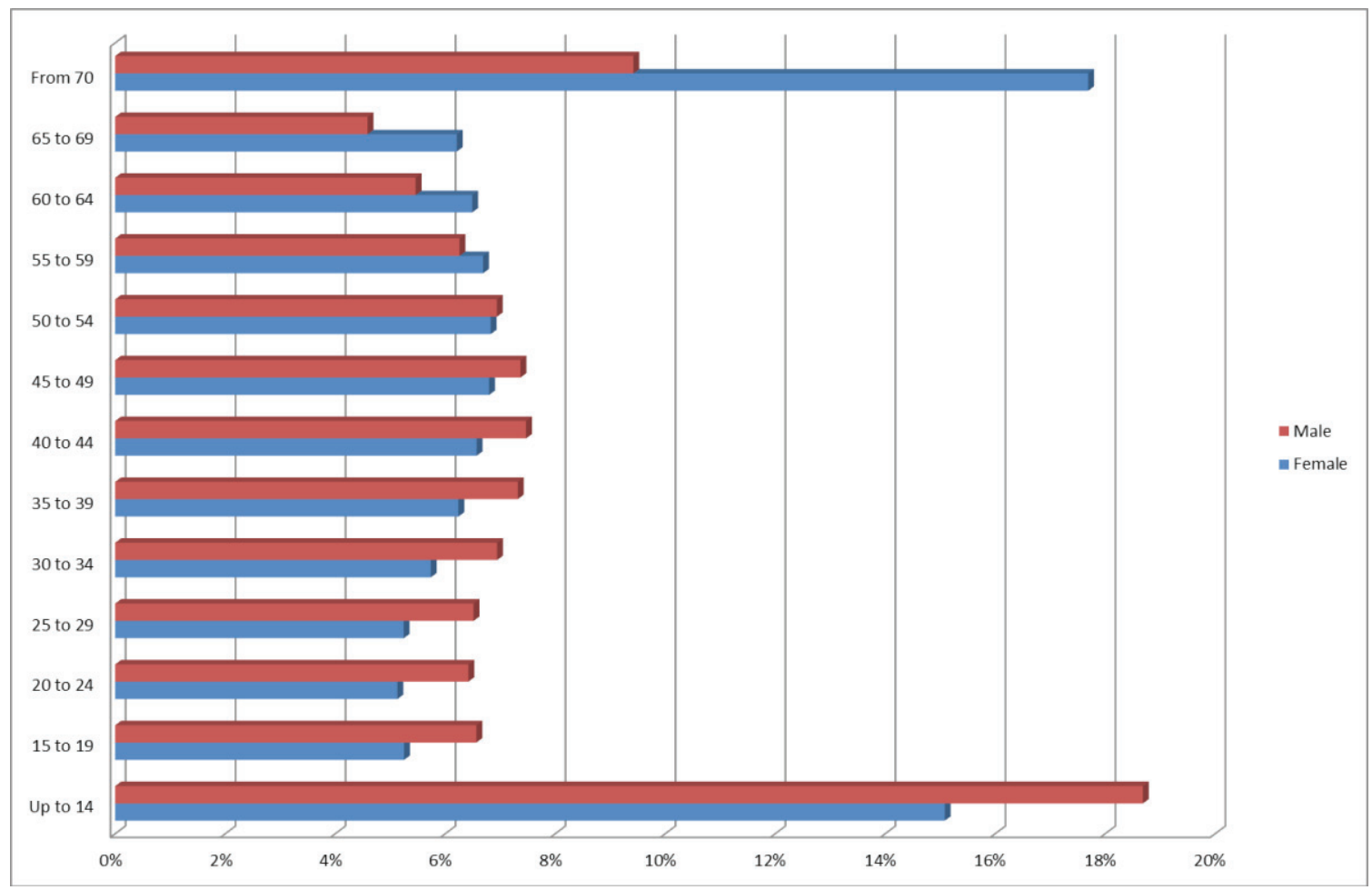

Figure 8. Population structure by age and gender: Scenario 1, 2013

Source: author's calculations based on data from Central Statistical Bureau of Latvia [www.csb.gov.lv]

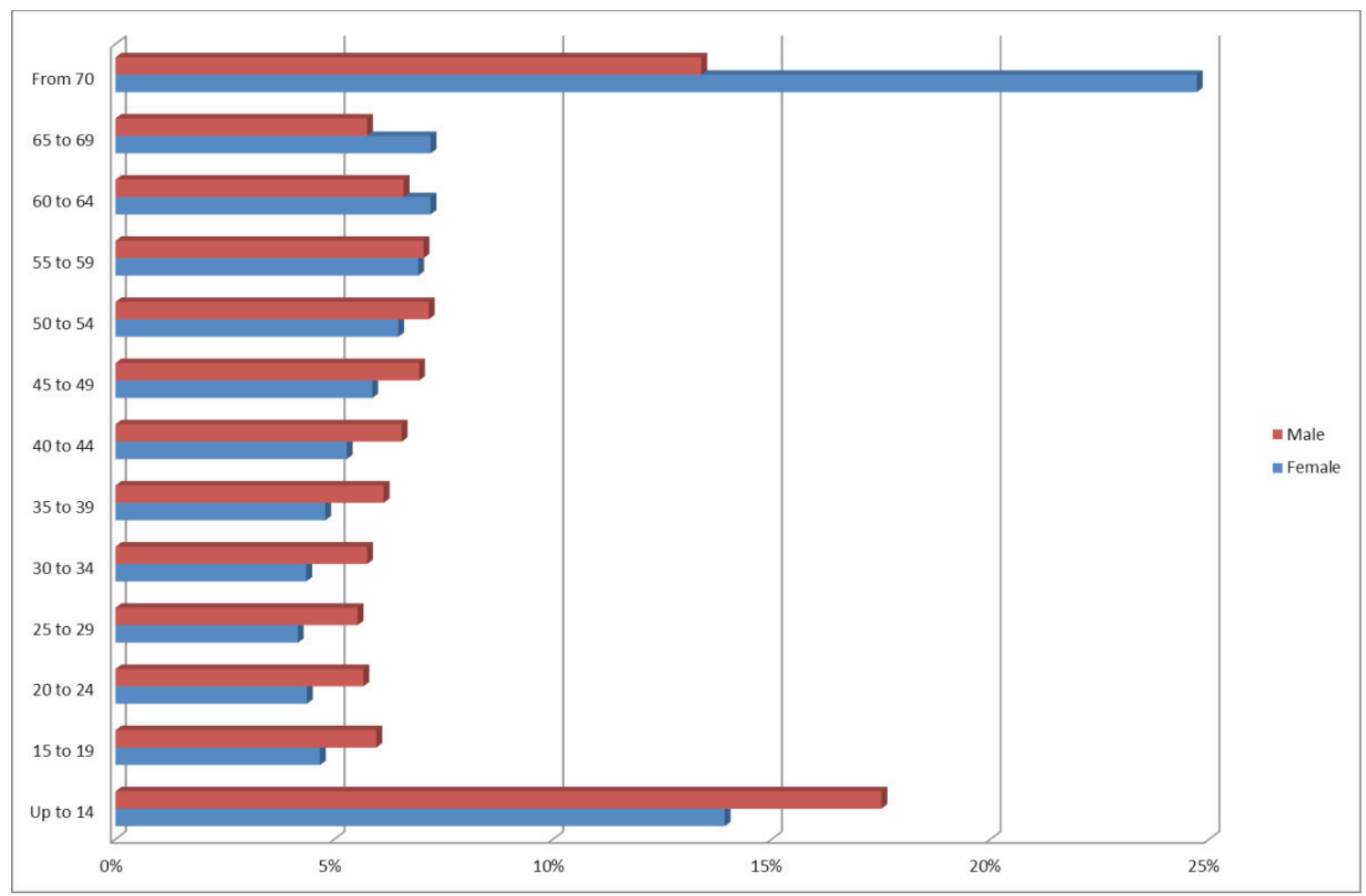

Figure 9. Population structure by age and gender: Scenario 1, 2030

Source: author's calculations based on data from Central Statistical Bureau of Latvia [www.csb.gov.lv] 


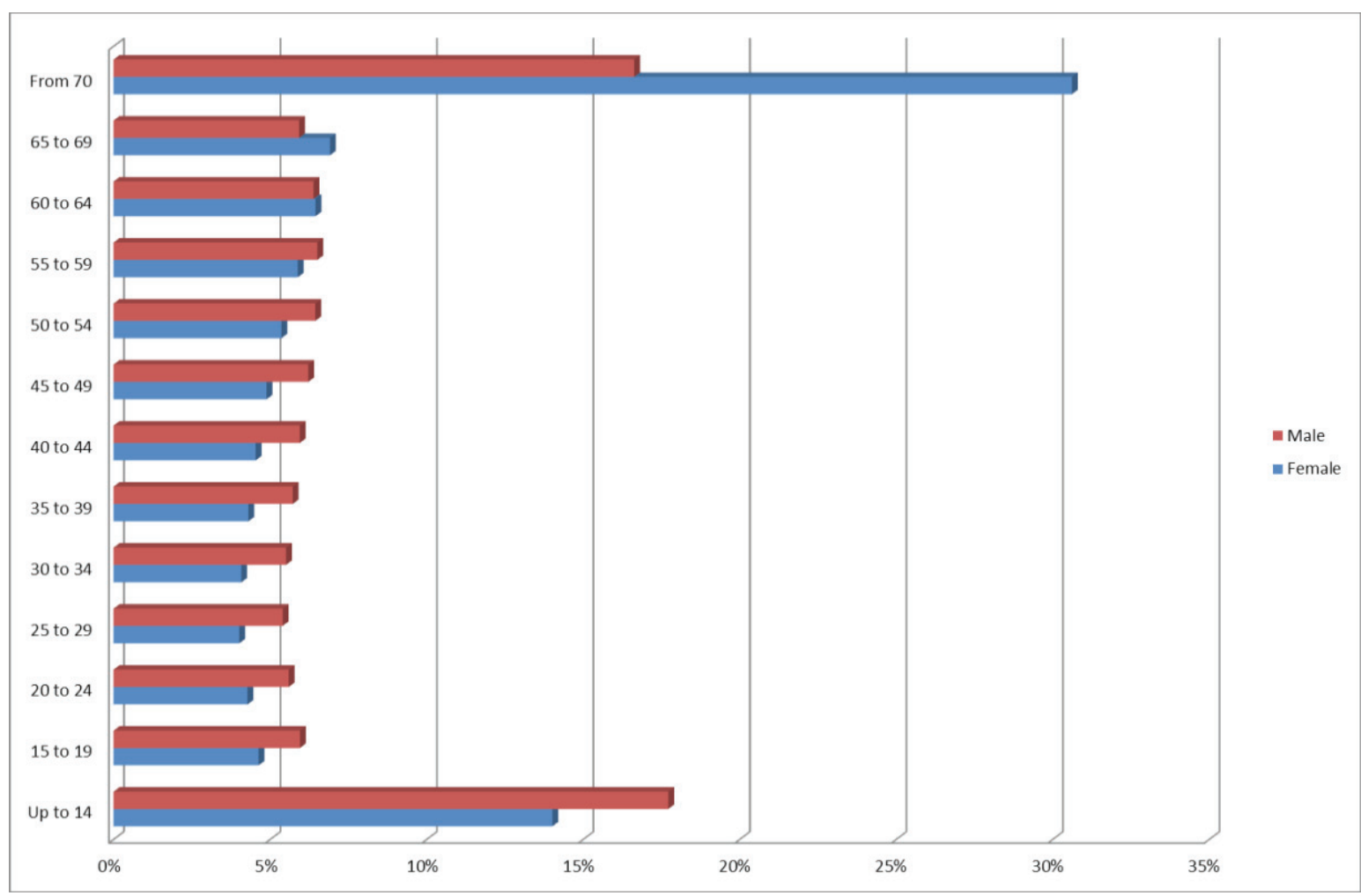

Figure 10. Population structure by age and gender: Scenario 1, 2050

Source: author's calculations based on data from Central Statistical Bureau of Latvia [www.csb.gov.lv]

Age groups of working age (15-65) change from $61 \%$ to $48 \%$ for female and from $67 \%$ to $59 \%$ for male. Elder residents (from 65 ) fraction increases from $24 \%$ to $38 \%$ for female and from $14 \%$ to $23 \%$ for male, but young residents (up to 15) share decreases for $1 \%$. Demographic burden increases from 560 to 867 .

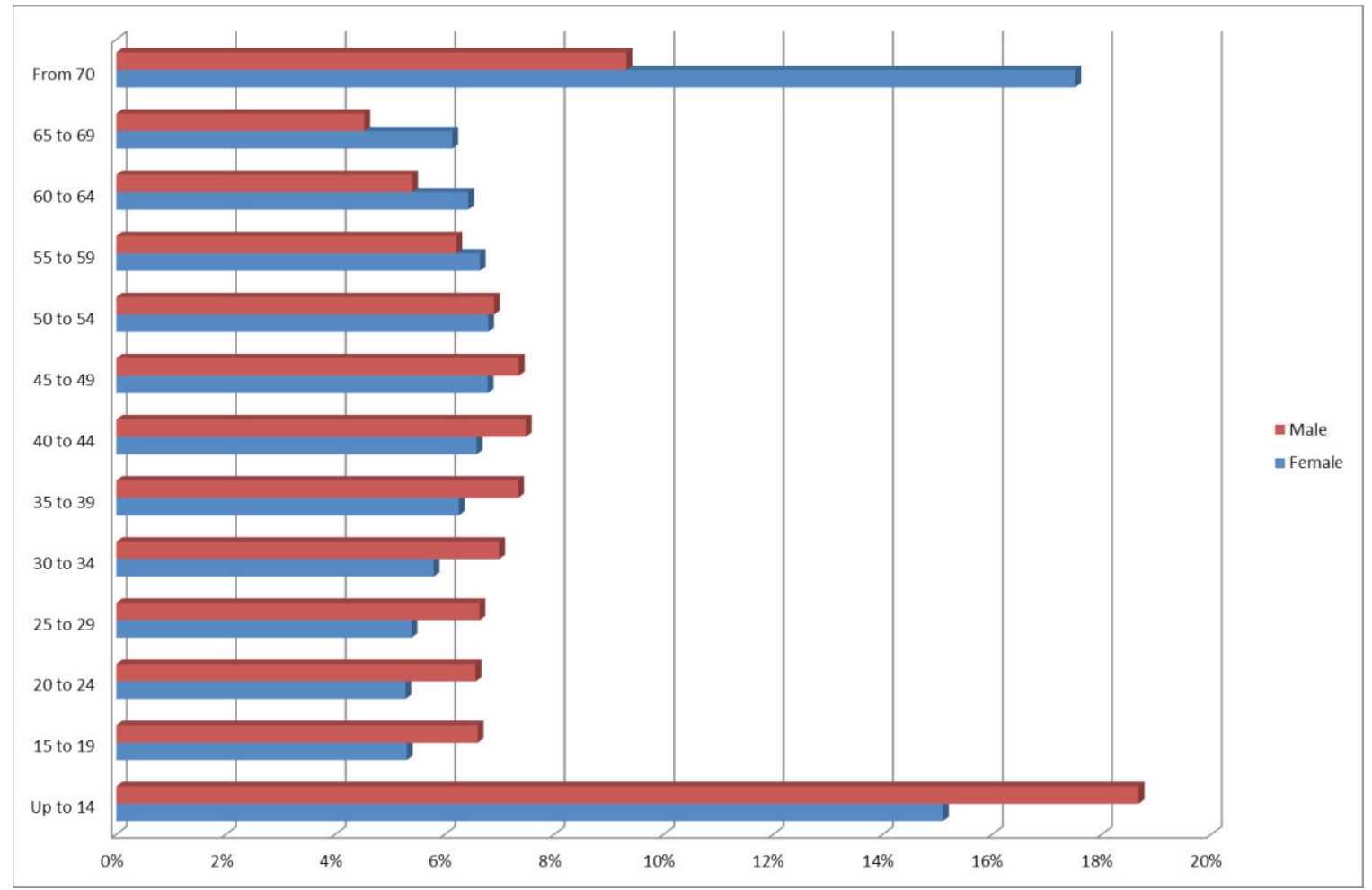

Figure 11. Population structure by age and gender: Scenario 3, 2013

Source: author's calculations based on data from Central Statistical Bureau of Latvia [www.csb.gov.lv] 
Similar tendency remains even for the "most optimistic" scenario without any emigration (Figures 11, $12,13)$.

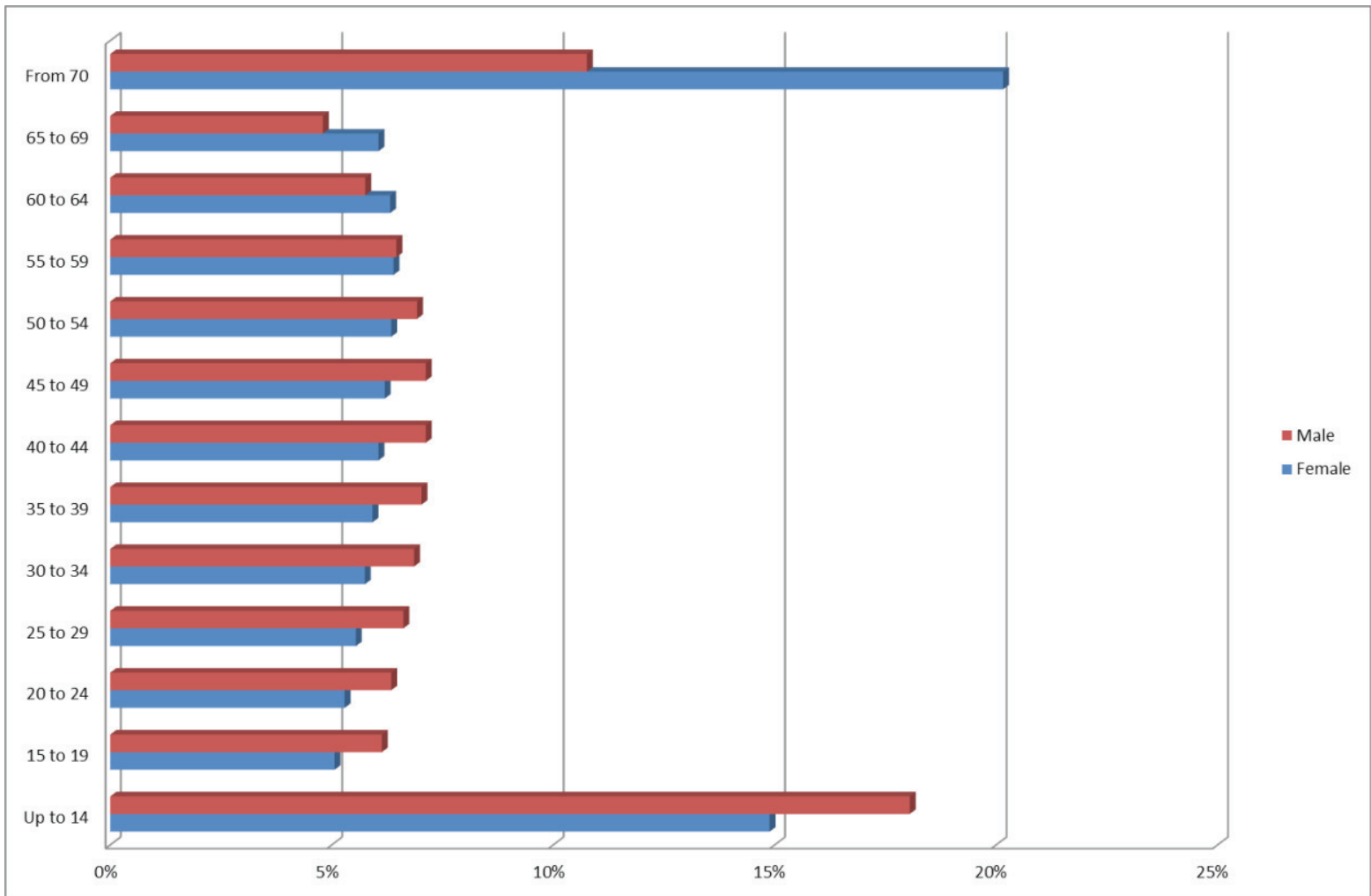

Figure 12. Population structure by age and gender: Scenario 3, 2030

Source: author's calculations based on data from Central Statistical Bureau of Latvia [www.csb.gov.lv]

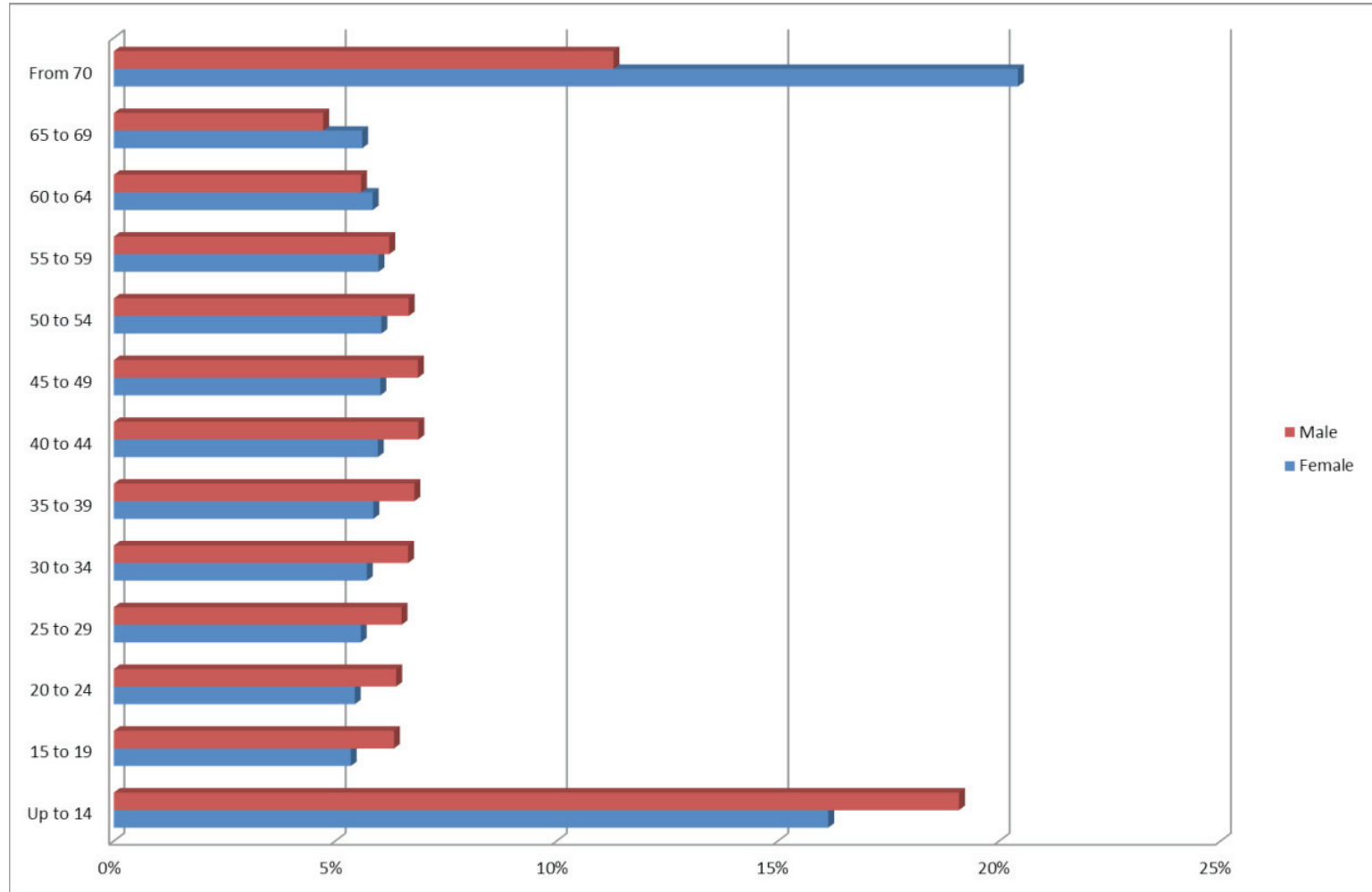

Figure 13. Population structure by age and gender: Scenario 3, 2050

Source: author's calculations based on data from Central Statistical Bureau of Latvia [www.csb.gov.lv] 
Age groups of working age (15-65) change from $61 \%$ to $58 \%$ for female and from $67 \%$ to $65 \%$ for male. Elder residents (from 65 ) fraction increases from $24 \%$ to $26 \%$ for female and from $14 \%$ to $16 \%$ for male, but younger residents (up to 15) share remains stable even showing $1 \%$ increase. Demographic burden is growing slowly and reaches maximum value of 636 in year 2050.

Taking for granted the OECD forecast for GDP growth, GDP per capita dynamics had been calculated for all scenarios (Figure 14).

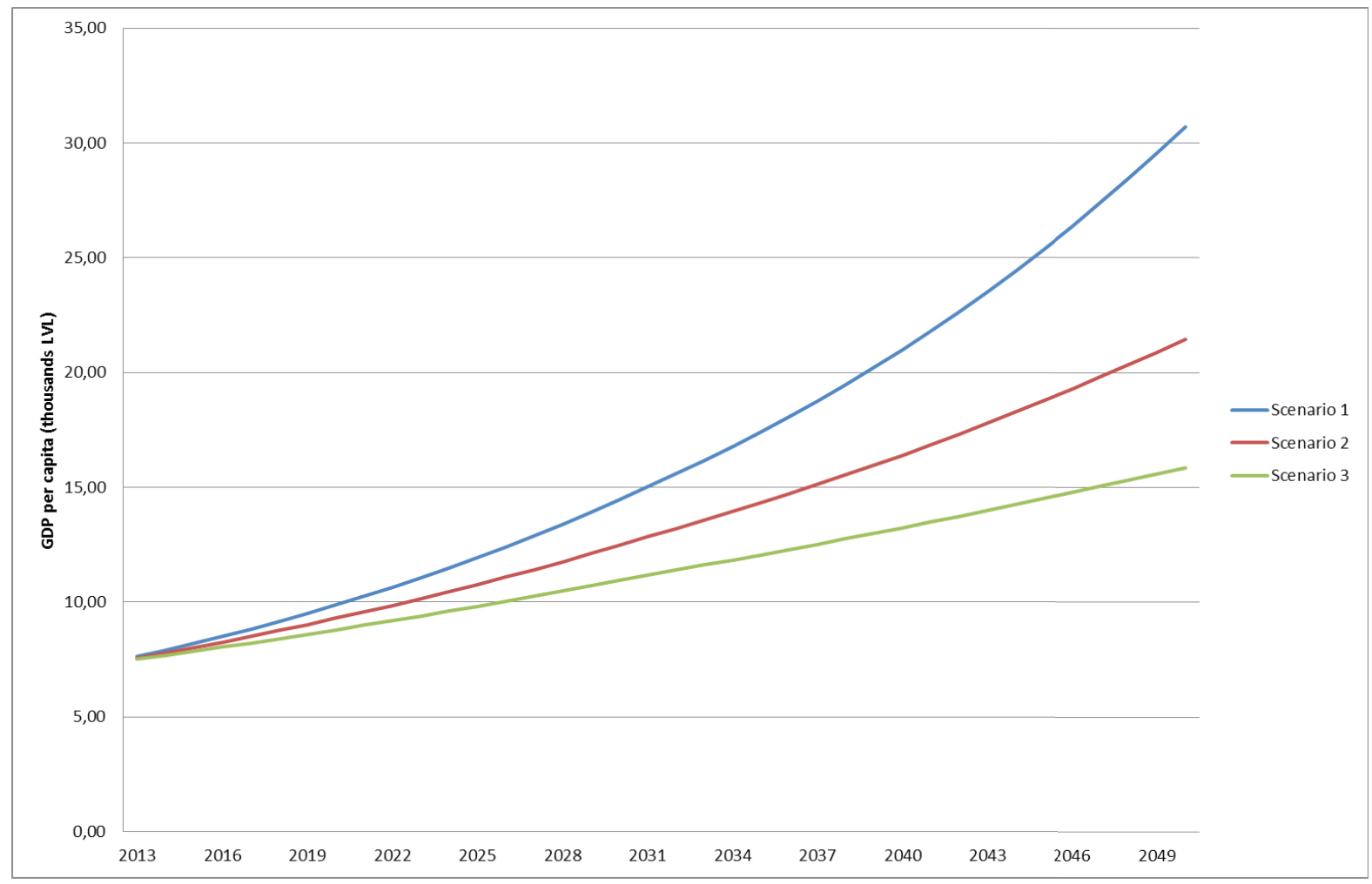

Figure 14. GDP per capita

Source: author's calculations based on data from Central Statistical Bureau of Latvia [www.csb.gov.lv]

It's clearly seen that GDP share per one person increases from 2 up to 4.5 times within selected time horizon. Main cause of such change is forecasted population decline while GDP inclines. Even if the most optimistic scenario fulfills, there is going to be doubling of GDP per capita. That can be achieved either by involving additional labor resources (what is not going along with the trend) or production performance increase.

\section{Conclusions and recommendations}

System dynamics is to be one of the most suitable methods to calculate scenarios of social economic development.

Population aging and lack of residents of fertile age affects the birth rate, thus worsening demographic situation in Latvia within time horizon up to 2050.

There is going to be a serious shift in population age structure, so that overall demographic burden may significantly increase, even within next 20 years. It means, that at least two serious problems will strengthen growing social budget expenses and lack of labor force. Even implementing effective social policy, volume of labor force in Latvia may scale down by $10-35 \%$ within next 20 years and by $10-60 \%$ by 2050 . There- 
fore, employment of people, both elder of working age and over working age is becoming very important for government and business.

Due to low birthrate, number of children may decrease for $16-44 \%$ within next 20 years and for $25-67 \%$ by 2050 , thus affecting social development in general and education sector in particular. Actions intended to increase birth rate can be a good tool for government to improve demographic situation in Latvia. Although these actions may cause demographic burden growth in short-term, it will be insignificant.

Uncontrolled(by age groups) immigration may cause demographic burden growth, unchanging the population development trends. Higher and special education export could be a good decision to support educational sector, as well as to improve social economic situation by selective immigration. This can be expressed as interconnected reinforcing loops, where growing educated labor force attracts investments and growing possibilities stimulates labor force.

Continuous investing in production performance and education will support long-term growth of GDP while population will decline.

Further model development will involve factors such as: investments, productivity, production and consumption; fertility rate will consider social economic paradox. Next version will use more factors and fewer assumptions, thus making it as independent as possible.

\section{References}

Bossel, H. (2007a). System Zoo 3. Simulation Models. Economy, Society, Development. Germany: Books on Demand $\mathrm{GmbH}$.

Bossel, H. (2007b). Systems and models. Complexity, Dynamics, Evolution, Sustainability. Germany: Books on Demand $\mathrm{GmbH}$.

Drucker, P. (2001). Management Challenges for 21st Century. Harper Business.

Forrester, J. W. (1961). Industrial Dynamics. MIT Press: Cambridge, MA.

Forrester, J. W. (1969). Urban Dynamics. Pegasus Communications.

Forrester, J. W. (1971). World Dynamics. Wright-Allen Press.

Gleick, J. (1987). Chaos: Making a New Science. New York: Viking.

Meadows, D., Randers, J., Meadows, D. (2012). Limits to Grow. USA: Chelsea Green Publishing.

Meadows, D. (2011). Thinking in Systems. A Primer. USA: Chelsea Green Publishing.

PwC Economics. (2013). World in 2050. The BRICs and beyond: prospects, challenges and opportunities.

Randers, J. (2012). 2052. A Global Forecast for the Next Forty Years. USA: Chelsea Green Publishing.

Richardson, G. P. (1991). System dynamics: Simulation for policy analysis from a feedback perspective. In: P. A. Fishwick, P. A. Luker (eds.). Qualitative simulation modeling and analysis. Springer-Verlag. New York, p. 144-169.

Richardson, G. P. (1996). System Dynamics. In: S. Gass, C. Harris (eds.). Encyclopedia of Operations Research and Management Science. Kluwer Academic Publishers, Norwell MA, p. 807-810.

Ruth, M., Hannon, B. (1997). Modeling dynamic economic systems. Springer Verlag, New York.

Sadovnichiy, V. A., Akayev, A. A., Korotayev, A. V., Malkov, S. Y. (2012). Modelling and Forecasting World Dynamics. Moscow. ISBN 978-5-7556-0456-7.

Sterman, J. D. (2000). Business dynamics. Systems thinking and modeling for a complex world. USA: Irwin McGrawHill.

Chateau, J., Rebolledo, C., Dellink, R. (2011). An Economic Projection to 2050: The OECD ENV-Linkages Model Baseline. OECD Environment Working Papers, no. 41. OECD Publishing.

Álvarez-Arenas, M., Mirón, I. (2006). A flexible framework for regional sustainable development indicators using system thinking criteria (INSURE). Revista Internacional Sostenibilidad, Tecnología y Humanismo, número 1, p. 41-59.

Cimren, E., Bassi, A., Fiksel, J. (2010: 2818). T21-Ohio, a System Dynamics Approach to Policy Assessment for Sustainable Development: A Waste to Profit Case Study. Sustainability 2010, 2. ISSN 2071-1050, p. 2814-2832.

Central Statistical Bureau of Latvia. Website: www.csb.gov.lv 


\section{PAGRINDINIUU LATVIJOS SOCIALINIO-EKONOMINIO VYSTYMOSI TENDENCIJŲ SISTEMINIS MODELIAVIMAS}

\section{AleXei Homutinin}

Daugavpils universitetas (Latvija)

\section{Santrauka}

Besitęsiantis Latvijos gyventojų skaičiaus mažèjimas ir populiacijos senėjimas kelia rimtą grèsmę šalies ekonominiam ir socialiniam vystymuisi. Šių procesų padariniai gali būti nesuderinti: socialinis biudžetas ir pensijų sistema, žmogiškujų išteklių trūkumas, sumažèjęs verslo aktyvumas, ir kt. Tai gali sukelti ekonomines ir politines krizes. Šioje situacijoje ypač svarbu laiku nustatyti neigiamas tendencijas ir priimti tinkamus strateginius sprendimus. Straipsnyje taikant sisteminį, dinaminį modeliavimą skiriami trys hipotetiniai Latvijos socialinio-ekonominio vystymosi scenarijai. Tyrimo naujumas susijęs su pasirinktais veiksniais, jų struktūra, priklausomybe ir paties modelio kūrimu. Tai leido apskaičiuoti populiacijos dinamiką ir jos struktūrą bei priklausomybę nuo BVP ir vidutinių pajamų. Parodytos dominuojančios Latvijos socialinioekonominio vystymosi tendencijos ir pateikta keletas rekomendacijų.

PAGRINDINIAI ŽODŽIAI: socialinis-ekonominis vystymasis, gyventoju pasiskirstymas pagal amžiu, simuliavimo modelis, scenarijaus analize.

JEL KLASIFIKACIJA: E200, J110, O290, O410, C320, C530 